\title{
Editorial: A virtude do espanto
}

$\mathbf{P}$ latão teria dito que a principal virtude do filósofo é a do espanto. A capacidade de olhar o mundo sem tomar os fenômenos por óbvios. A curiosidade da criança ao ver objetos caírem ao chão e a vivacidade do espírito que quer explicar como e porquê.

E que mundo temos para nos espantar! O espírito aguçado não se entedia com ele. É com esse olhar que percebo o nascimento de um fenômeno e de sua ciência. Com renovada admiração, um professional da ciência vê uma área do conhecimento crescer e dar frutos.

A Economia Criativa desenvolve-se no Brasil a passos largos. A tomada de consciência da afinidade entre atividades econômicas e das vantagens de considera-las em conjunto é acompanhada da tomada da consciência científica de que um novo fenômeno existe e merece a atenção de cientistas.

Foi assim que a ESPM planejou e organizou o seu mestrado profissional em Gestão da Economia Criativa. Que origina-se no Rio de Janeiro, onde as vocações da cidade e do estado já há tempos alcançam eco na unidade carioca da escola.

Iniciado o mestrado, que tem por função colocar cientistas dentro de organizações da sociedade, estendendo o olhar da ciência para além das fronteiras universitárias, a escola chama a área ao diálogo.

Como fazer conversarem-se entre si as diversidades contidas nessa nova área de atividade e de estudo? Esta é a proposta da revista acadêmica Diálogos com a Economia Criativa: registrar o olhar da ciência para ela, promover o encontro e a polêmica das ideias, desenvolver a teoria científica e nosso conhecimento sobre este mundo.

A ESPM, há 65 anos caracterizando-se pelo pioneirismo de atuação e de olhar, inova na atuação - na formação de jovens talentos capazes de desenvolverem a Economia Criativa de forma profissional e científica, na pesquisa e produção de conhecimento sobre a nova área - e na criação de veículos onde a teoria possa ser discutida e adentrar o patrimônio do conhecimento humano.

Diálogos com a Economia Criativa é um tal veículo pioneiro. Um convite ao espanto diante do desenvolvimento das atividades criativas.

Espantemo-nos!

Prof. Dr. Marcos Amatucci

Pró-Reitor de Pesquisa e Pós-Graduação Stricto Sensu da ESPM

ESPM, 1 de maio de 2016. 